\title{
A rapid and efficient synthetic route to terminal aryl- acetylenes by tetrabutylammonium hydroxide- and methanol-catalyzed cleavage of 4-aryl-2-methyl-3-butyn-2-ols
}

Jie Li and Pengcheng Huang*

\author{
Letter \\ Address: \\ Department of Polymer Materials and Composites, School of \\ Materials Science and Engineering, Beihang University, Beijing \\ 100191, China

\section{Email:} \\ Jie Li - lijie1159@mse.buaa.edu.cn; Pengcheng Huang* - \\ huangpc@buaa.edu.cn \\ * Corresponding author \\ Keywords: \\ 4-aryl-2-methyl-3-butyn-2-ol; deprotection reaction; \\ 2-methyl-3-butyn-2-ol; terminal alkynes; tetrabutylammonium \\ hydroxide
}

\author{
Beilstein J. Org. Chem. 2011, 7, 426-431. \\ doi:10.3762/bjoc.7.55 \\ Received: 15 February 2011 \\ Accepted: 25 March 2011 \\ Published: 13 April 2011 \\ Associate Editor: B. Stoltz \\ (c) $2011 \mathrm{Li}$ and Huang; licensee Beilstein-Institut. \\ License and terms: see end of document.
}

\begin{abstract}
Tetrabutylammonium hydroxide with methanol as an additive was found to be a highly active catalyst for the cleavage of 4-aryl-2methyl-3-butyn-2-ols. The reaction was performed at $55-75^{\circ} \mathrm{C}$ and gave terminal arylacetylenes in good to excellent yields within several minutes. Compared with the usual reaction conditions (normally $>110{ }^{\circ} \mathrm{C}$, several hours), this novel catalyst system can dramatically decrease the reaction time under much milder conditions.
\end{abstract}

\section{Introduction}

Terminal arylacetylenes are key precursors for the construction of conjugated oligo- or polyarylacetylenes, which have been widely used in the preparation of photoelectric devices such as organic light-emitting diodes (OLEDs) [1-4], field-effect transistors (OFETs) [5,6], and organic photovoltaic cells (OPVCs) [7-9]. The palladium-catalyzed Sonogashira cross-coupling of an aryl halide with a mono-protected acetylene and the subsequent removal of the protecting group is an important synthetic approach to access terminal arylacetylenes [10-13]. The commonly used mono-protected acetylenes are trialkylsilylacetylenes such as trimethylsilylacetylene (TMSA), triisopropylsilylacetylene (TIPSA) and [(3-cyanopropyl)dimethylsilyl]acetylene (CPDMSA), and 2-methyl-3-butyn-2-ol (MEBYNOL). The trialkylsilyl groups can be easily removed by treatment with oxygen-based nucleophiles or fluoride at ambient temperature [10-12]. However, trialkylsilylacetylenes are rather expensive that their use is limited to small-scale synthesis [13]. On the other hand, MEBYNOL ( $\$ 0.3 / \mathrm{g})$ is much cheaper than trialkylsilylacetylenes (TMSA \$14.0/g, TIPSA \$20.6/g, from Alfa Aesar). 
MEBYNOL couples with aryl halides in nearly quantitative yield and the coupling products 4-aryl-2-methyl-3-butyn-2-ols can be easily purified by chromatography because of the very different chromatographic polarities between the products and the aryl halides [13-22]. Nevertheless, the existing methods for the deprotection reaction (cleavage of 4-aryl-2-methyl-3-butyn2-ols by removal of 2-hydroxypropyl group) to produce arylacetylenes often require harsh conditions [13-22], such as strong base ( $\mathrm{NaH}, \mathrm{NaOH}, \mathrm{KOH}$ or $t$-BuOK), high temperature (in refluxing toluene or butanol) and a long reaction time. Such forcing conditions frequently lead to undesired side reactions and limit the application of MEBYNOL in the preparation of terminal arylacetylenes.

To solve the problem, herein we report a novel efficient catalyst system consisting of tetrabutylammonium hydroxide $\left(\mathrm{Bu}_{4} \mathrm{NOH}\right)$ and methanol for the removal of the 2-hydroxypropyl group from 4-aryl-2-methyl-3-butyn-2-ols under mild conditions. This deprotection reaction is remarkably facile (5-30 min, $55-75^{\circ} \mathrm{C}$ ) in comparison to the existing methods (usually several hours, $>110{ }^{\circ} \mathrm{C}$ ) [13-22] and gives the terminal arylacetylene products in good to excellent yields (up to $98 \%$ ).

\section{Results and Discussion}

Initially, we chose 4-(4-(phenylethynyl)phenyl)-2-methyl-3butyn-2-ol (1a) as the model compound and carried out the deprotection reaction in toluene at $75^{\circ} \mathrm{C}$ in the presence of inorganic bases and $\mathrm{Bu}_{4} \mathrm{NOH} / \mathrm{CH}_{3} \mathrm{OH}$, respectively (Table 1). It was found that by using inorganic bases, such as $\mathrm{NaH}, \mathrm{NaOH}$, $\mathrm{NaOAc}, \mathrm{KOH}$ and $\mathrm{K}_{2} \mathrm{CO}_{3}$, no deprotected product $2 \mathrm{a}$ was detected by TLC even after $24 \mathrm{~h}$ (Table 1, entries 1-5). Terminal arylacetylene 2a was obtained in good yield only by $\mathrm{NaOH}$ with the addition of water and $\mathrm{Bu}_{4} \mathrm{NI}$ (the phase transfer catalyst), but this reaction required $23 \mathrm{~h}$ (Table 1, entry 6). Using $\mathrm{Bu}_{4} \mathrm{NOH}$ as the catalyst with $\mathrm{CH}_{3} \mathrm{OH}$ as an additive, $2 \mathbf{a}$ was obtained in yields as high as $98 \%$ after only $5 \mathrm{~min}$ (Table 1 , entry 7).

The influence of the loading of $\mathrm{Bu}_{4} \mathrm{NOH}$ and $\mathrm{CH}_{3} \mathrm{OH}$, as well as the effect of temperature on the yield of $\mathbf{2 a}$ were then investigated (Table 2). The yield decreased from $98 \%$ to $29 \%$ when the $\mathrm{Bu}_{4} \mathrm{NOH}$ loading relative to $1 \mathrm{a}$ decreased from $10 \mathrm{~mol} \%$ to $2.5 \mathrm{~mol} \%$ (Table 2, entries 1, 2 and 5), suggesting that $10 \mathrm{~mol} \%$ of $\mathrm{Bu}_{4} \mathrm{NOH}$ was required. The optimum quantity of $\mathrm{CH}_{3} \mathrm{OH}$ was 1.2 equiv with respect to the amount of $1 \mathrm{a}$. The yield increased with increasing $\mathrm{CH}_{3} \mathrm{OH}$ loading when the mole ratio $\mathrm{CH}_{3} \mathrm{OH} / \mathbf{1}$ a was lower than 1.2 (Table 2, entries 2-4), but it decreased with increasing $\mathrm{CH}_{3} \mathrm{OH}$ loading when the mole ratio $\mathrm{CH}_{3} \mathrm{OH} / \mathbf{1 a}$ was higher than 1.2 (Table 2, entries 5-7). Using $10 \mathrm{~mol} \%$ of $\mathrm{Bu}_{4} \mathrm{NOH}$ and 1.2 equiv of $\mathrm{CH}_{3} \mathrm{OH}$, 2 a was obtained in good to excellent yields in a relatively wide temperature range of $55-85^{\circ} \mathrm{C}$ (Table 2 , entries $5,8-13$ ). It reached the highest yield of $98 \%$ at $75{ }^{\circ} \mathrm{C}$ within $5 \mathrm{~min}$. The yield was reduced significantly when the temperature was lower than $55^{\circ} \mathrm{C}$. Compared to the conventional method $\left(>110^{\circ} \mathrm{C}\right)$, this lower reaction temperature of $55-75^{\circ} \mathrm{C}$ is especially meaningful for the 4-aryl-2-methyl-3-butyn-2-ols containing temperature-sensitive groups.

Thus, the optimal deprotection reaction required $10 \mathrm{~mol} \%$ of $\mathrm{Bu}_{4} \mathrm{NOH}$ with 1.2 equiv of $\mathrm{CH}_{3} \mathrm{OH}$ in toluene at $75^{\circ} \mathrm{C}$. Then the deprotection reaction was investigated for different 4-aryl-2methyl-3-butyn-2-ols. As shown in Table 3, this method was rapid, efficient and worked well with a broad range of 4-aryl-2methyl-3-butyn-2-ols. Regarding the most studied 4-aryl-2methyl-3-butyn-2-ols (Table 3, entries 1-4, 6, 7 and 9-11), the deprotection reaction was complete within $5 \mathrm{~min}$ at $75{ }^{\circ} \mathrm{C}$,

Table 1: Removal of 2-hydroxypropyl group in the presence of different catalysts ${ }^{a}$.

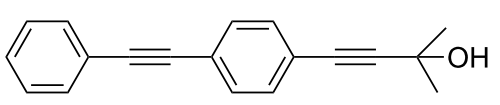

$1 \mathbf{a}$

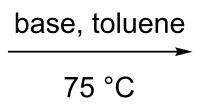

$75^{\circ} \mathrm{C}$

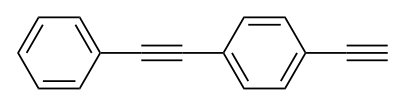

$2 \mathbf{a}$

\begin{tabular}{|c|c|c|c|}
\hline Entry & Base (equiv) & Time (h) & Yield $(\%)^{\mathrm{b}}$ \\
\hline 1 & $\mathrm{KOH}(5)$ & 24 & 0 \\
\hline 2 & $\mathrm{~K}_{2} \mathrm{CO}_{3}(5)$ & 24 & 0 \\
\hline 3 & $\mathrm{NaOAc}(5)$ & 24 & 0 \\
\hline 4 & $\mathrm{NaH}(5)$ & 24 & 0 \\
\hline 5 & $\mathrm{NaOH}(5)$ & 24 & 0 \\
\hline 6 & $5 \mathrm{M}$ aqueous $\mathrm{NaOH}(75)$ with $\mathrm{Bu}_{4} \mathrm{NI}(0.1)$ & 23 & 89 \\
\hline 7 & $\mathrm{Bu}_{4} \mathrm{NOH}(0.1)$ with $\mathrm{CH}_{3} \mathrm{OH}(1.2)$ & 0.08 & 98 \\
\hline
\end{tabular}

aReaction conditions: $1 \mathrm{a}(2 \mathrm{mmol})$, base in toluene $(100 \mathrm{~mL})$ at $75^{\circ} \mathrm{C}$, under $\mathrm{N}_{2}$. ${ }^{\text {blsolated yield. }}$ 
Table 2: Effect of reaction conditions on the yield of $2 a$.

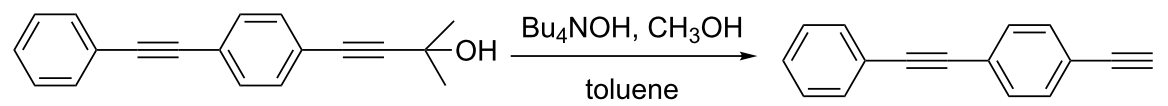

$1 a$

$2 a$

\begin{tabular}{|c|c|c|c|c|c|}
\hline Entry & $\mathrm{Bu}_{4} \mathrm{NOH}(\mathrm{mol} \%)$ & $\mathrm{CH}_{3} \mathrm{OH}$ (equiv) & Temp $\left({ }^{\circ} \mathrm{C}\right)$ & Time (min) & Yield $(\%)^{b}$ \\
\hline 1 & 2.5 & 1.2 & 75 & 45 & 29 \\
\hline 2 & 5 & 1.2 & 75 & 30 & 80 \\
\hline 3 & 5 & 1.0 & 75 & 30 & 70 \\
\hline 4 & 5 & 0.6 & 75 & 30 & 68 \\
\hline 5 & 10 & 1.2 & 75 & 5 & 98 \\
\hline 6 & 10 & 1.9 & 75 & 5 & 92 \\
\hline 7 & 10 & 3.2 & 75 & 5 & 80 \\
\hline 8 & 10 & 1.2 & 85 & 5 & 92 \\
\hline 9 & 10 & 1.2 & 65 & 5 & 95 \\
\hline 10 & 10 & 1.2 & 55 & 30 & 87 \\
\hline 11 & 10 & 1.2 & 45 & 30 & 28 \\
\hline 12 & 10 & 1.2 & 35 & 30 & 15 \\
\hline 13 & 10 & 1.2 & 25 & 600 & 0 \\
\hline
\end{tabular}

aReaction conditions: $1 \mathrm{a}(2 \mathrm{mmol}), \mathrm{Bu}_{4} \mathrm{NOH}$ and $\mathrm{CH}_{3} \mathrm{OH}$ in toluene $(100 \mathrm{~mL})$, under $\mathrm{N}_{2}$. ${ }^{\text {bl solated yield. }}$

Table 3: Synthesis of different terminal arylacetylenes by removal of 2-hydroxypropyl groups under optimal conditions ${ }^{\mathrm{a}}$.

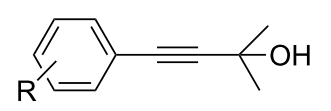

$1 \mathrm{a}-\mathrm{h}$
$\frac{\mathrm{Bu}_{4} \mathrm{NOH}(10 \mathrm{~mol} \%), \mathrm{CH}_{3} \mathrm{OH} \text { (1.2 equiv) }}{\text { toluene } 75^{\circ} \mathrm{C}}$ toluene, $75^{\circ} \mathrm{C}$

$\mathrm{R}$

Entry


Table 3: Synthesis of different terminal arylacetylenes by removal of 2-hydroxypropyl groups under optimal conditions ${ }^{a}$. (continued)

6

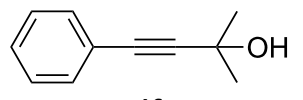

$1 f$

7

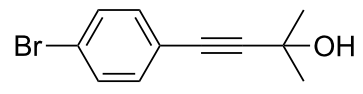

$1 \mathrm{~g}$

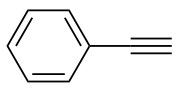

$2 f$

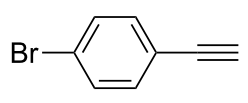

2g
88

5
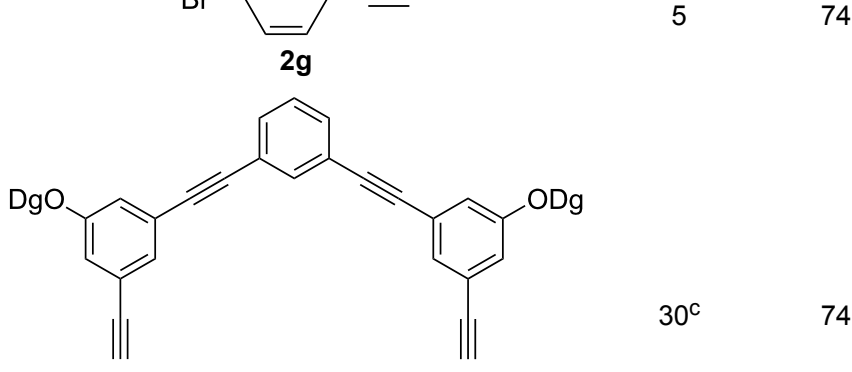

$30^{c}$

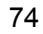

$\mathrm{Dg}=\left(\mathrm{CH}_{2} \mathrm{CH}_{2} \mathrm{O}\right)_{2} \mathrm{CH}_{2} \mathrm{CH}_{3}$

$2 \mathrm{~h}$<smiles>C#Cc1cc(C#C)cc(C#C)c1</smiles>

$2 \mathbf{i}$<smiles>C#Cc1cc(C#C)cc(C#C)c1</smiles>

5
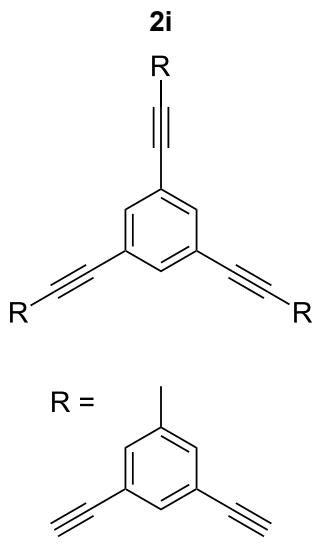

85

91



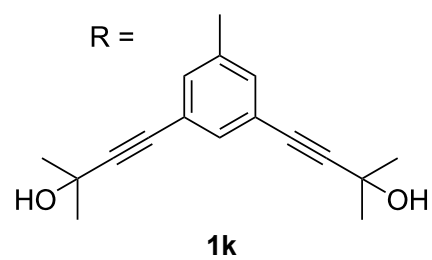

$2 k$

aReaction conditions: 4-aryl-2-methyl-3-butyn-2-ol (2 mmol), $\mathrm{Bu}_{4} \mathrm{NOH}\left(0.1 \mathrm{~mol}\right.$ per $1 \mathrm{~mol}$ 2-hydroxypropyl group), $\mathrm{CH}_{3} \mathrm{OH}(1.2 \mathrm{~mol}$ per $1 \mathrm{~mol}$ 2-hydroxypropyl group) and toluene $(100 \mathrm{~mL})$ under a $\mathrm{N}_{2}$ atmosphere. ${ }^{\mathrm{b}}$ Isolated yields. ${ }^{\mathrm{C}}$ The reaction was carried out at $75{ }^{\circ} \mathrm{C}$ for $15 \mathrm{~min}$, then at $90{ }^{\circ} \mathrm{C}$ for $15 \mathrm{~min}$. 
giving the terminal arylacetylenes in good to excellent yields. Products phenylacetylene (2f) was a liquid with a boiling point of $142{ }^{\circ} \mathrm{C}$ and 4-bromophenylacetylene (2g) was a solid that sublimed, consequently some of these compounds were lost during purification (Table 3, entries 6 and 7). Arylacetylenes 1e and $1 \mathrm{~h}$ bearing electron-donating groups showed low reactivity [22], and the reactions required heating at $75^{\circ} \mathrm{C}$ for $15 \mathrm{~min}$ then at $90{ }^{\circ} \mathrm{C}$ for $15 \mathrm{~min}$ (Table 3, entries 5 and 8 ). However, the reaction conditions were still milder than those of existing methods $(>3 \mathrm{~h})$ and satisfactory yields were achieved. It is worth mentioning that for the 4-aryl-2-methyl-3-butyn-2-ols containing two or more butynols, complete deprotection was achieved in only 5-30 min with good yields (Table 3, entries 8-11) using our method, whilst by using the conventional method deprotection was incomplete or the yields were low, or longer reaction times were required [22-25]. For example, multifunctional arylacetylenes $\mathbf{2 i}$ and $\mathbf{2 k}$ were prepared in $85 \%$ and $83 \%$ yields in $5 \mathrm{~min}$ (Table 3, entries 10 and 11), whereas they were obtained in only $38 \%$ and $11 \%$ yields in $8 \mathrm{~h}$, respectively, when sodium was used in refluxing toluene (Supporting Information File 1). Thus, our novel catalyst system may find applications for the preparation of arylacetylene dendritic macromolecules in high yield.

\section{Conclusion}

In summary, a rapid, simple, and efficient method has been developed for the preparation of terminal arylacetylenes by the removal of the 2-hydroxypropyl group from 4-aryl-2-methyl-3butyn-2-ols. By using $10 \mathrm{~mol} \% \mathrm{Bu}_{4} \mathrm{NOH}$ as the catalyst with the addition of 1.2 equiv of $\mathrm{CH}_{3} \mathrm{OH}$ at $55-75{ }^{\circ} \mathrm{C}$ complete deprotection was achieved within several minutes with good to excellent yields (up to 98\%). This method has good functional group tolerance and shows significant promise for the preparation of arylacetylenes with multiple terminal ethynyl groups such as dendritic macromolecules, which will broaden the application of the low-cost reagent 2-methyl-3-butyn-2-ol in the preparation of arylacetylenes.

\section{Experimental}

General procedure for the deprotection reaction using $\mathrm{Bu}_{4} \mathrm{NOH}$ as base with $\mathrm{CH}_{3} \mathrm{OH}$ in toluene: Under a nitrogen atmosphere, 4-aryl-2-methyl-3-butyn-2-ol (2 mmol) was dissolved into anhydrous toluene $(100 \mathrm{~mL})$ and the solution was heated to $75^{\circ} \mathrm{C}$, then $\mathrm{Bu}_{4} \mathrm{NOH}, 40$ wt \% solution in $\mathrm{CH}_{3} \mathrm{OH}$ ( $\mathrm{Bu}_{4} \mathrm{NOH}$ : $0.1 \mathrm{~mol}$ per $1 \mathrm{~mol}$ 2-hydroxypropyl group) was added. The mixture was stirred at $75^{\circ} \mathrm{C}$ for the indicated time. After cooling down to room temperature, the mixture was washed successively with $5 \% \mathrm{HCl}$ and brine, dried over $\mathrm{MgSO}_{4}$, and concentrated in vacuo. The crude product was then purified by column chromatography to afford the product.

\section{Supporting Information}

\section{Supporting Information File 1}

General experimental methods, analytical data, ${ }^{1} \mathrm{H}$ and

${ }^{13} \mathrm{C}$ NMR spectra of compounds $\mathbf{1 a}-\mathbf{k}$ and $\mathbf{2 a}-\mathbf{k}$.

[http://www.beilstein-journals.org/bjoc/content/

supplementary/1860-5397-7-55-S1.pdf]

\section{References}

1. Park, J.-H.; Lee, D. H.; Kong, H.; Park, M.-J.; Jung, I. H.; Park, C. E.; Shim, H.-K. Org. Electron. 2010, 11, 820-830. doi:10.1016/j.orgel.2010.01.024

2. Grimsdale, A. C.; Chan, K. L.; Martin, R. E.; Jokisz, P. G.; Holmes, A. B. Chem. Rev. 2009, 109, 897-1091. doi:10.1021/cr000013v

3. Liu, J.; Lam, J. W. Y.; Tang, B. Z. Chem. Rev. 2009, 109, 5799-5867. doi:10.1021/cr900149d

4. Mao, G.; Orita, A.; Fenenko, L.; Yahiro, M.; Adachi, C.; Otera, J. Mater. Chem. Phys. 2009, 115, 378-384. doi:10.1016/j.matchemphys.2008.12.015

5. Silvestri, F.; Marrocchi, A.; Seri, M.; Kim, C.; Marks, T. J.; Facchetti, A.; Taticchi, A. J. Am. Chem. Soc. 2010, 132, 6108-6123. doi:10.1021/ja910420t

6. Dong, H.; Li, H.; Wang, E.; Yan, S.; Zhang, J.; Yang, C.; Takahashi, I.; Nakashima, H.; Torimitsu, K.; Hu, W. J. Phys. Chem. B 2009, 113, 4176-4180. doi:10.1021/jp811374h

7. Zhao, W.; Tong, B.; Shi, J.; Pan, Y.; Shen, J.; Zhi, J.; Chan, W. K.; Dong, Y. Langmuir 2010, 26, 16084-16089. doi:10.1021/la1022196

8. Nelson, J.; Kwiatkowski, J. J.; Kirkpatrick, J.; Frost, J. M. Acc. Chem. Res. 2009, 42, 1768-1778. doi:10.1021/ar900119f

9. Cheng, Y.-J.; Yang, S.-H.; Hsu, C.-S. Chem. Rev. 2009, 109, 5868-5923. doi:10.1021/cr900182s

10. Cheng, X.; Heyen, A. V.; Mamdouh, W.; Uji-i, H.; De Schryver, F.; Höger, S.; De Feyter, S. Langmuir 2007, 23, 1281-1286. doi:10.1021/la062360r

11. Sahoo, D.; Thiele, S.; Schulte, M.; Ramezanian, N.; Godt, A. Beilstein J. Org. Chem. 2010, 6, No. 57. doi:10.3762/bjoc.6.57

12. Höger, S.; Bonrad, K. J. Org. Chem. 2000, 65, 2243-2245. doi:10.1021/jo991746m

13. Königsberger, K.; Chen, G. P.; Wu, R. R.; Girgis, M. J.; Prasad, K.; Repic, O.; Blacklock, T. J. Org. Process Res. Dev. 2003, 7, 733-742. doi:10.1021/op034072x

14. Shi, J.; Jim, C. J. W.; Mahtab, F.; Liu, J.; Lam, J. W. Y.; Sung, H. H. Y.; Williams, I. D.; Dong, Y.; Tang, B. Z. Macromolecules 2010, 43, 680-690. doi:10.1021/ma9012658

15. Frigoli, S.; Fuganti, C.; Malpezzi, L.; Serra, S. Org. Process Res. Dev. 2005, 9, 646-650. doi:10.1021/op050080x

16. Nandy, R.; Sankararaman, S. Beilstein J. Org. Chem. 2010, 6 , 992-1001. doi:10.3762/bjoc.6.112

17. Ji, Z.; Li, S.; Li, Y.; Sun, W. Inorg. Chem. 2010, 49, 1337-1346. doi:10.1021/ic9009674

18. Novák, Z.; Nemes, P.; Kotschy, A. Org. Lett. 2004, 6, 4917-4920. doi:10.1021/ol047983f

19. Yi, C.; Hua, R.; Zeng, H.; Huang, Q. Adv. Synth. Catal. 2007, 349, 1738-1742. doi:10.1002/adsc.200600498

20. Cross, T. A.; Davis, M. Synth. Commun. 2008, 38, 499-516. doi:10.1080/00397910701796584 
21. Harada, S.; Takita, R.; Ohshima, T.; Matsunaga, S.; Shibasaki, M. Chem. Commun. 2007, 43, 948-950. doi:10.1039/b614958h

22. Melissaris, A. P.; Litt, M. H. J. Org. Chem. 1994, 59, 5818-5821. doi:10.1021/jo00098a051

23. Chen, S.; Yan, Q.; Li, T.; Zhao, D. Org. Lett. 2010, 12, 4784-4787. doi:10.1021/ol101914f

24. Trumbo, D. L.; Marvel, C. S. J. Polym. Sci., Part A: Polym. Chem. 1986, 24, 2311-2326. doi:10.1002/pola.1986.080240924

25. Onopchenko, A.; Sabourin, E. T.; Selwitz, C. M. J. Org. Chem. 1979, 44, 1233-1237. doi:10.1021/jo01322a008

\section{License and Terms}

This is an Open Access article under the terms of the Creative Commons Attribution License

(http://creativecommons.org/licenses/by/2.0), which permits unrestricted use, distribution, and reproduction in any medium, provided the original work is properly cited.

The license is subject to the Beilstein Journal of Organic Chemistry terms and conditions:

(http://www.beilstein-journals.org/bjoc)

The definitive version of this article is the electronic one which can be found at: doi:10.3762/bjoc. 7.55 